\title{
Modal Sosial Petani dalam Peningkatan Produktifitas Pertanian di Kelurahan Biraeng Kecamatan Minasate'ne Kabupaten Pangkep
}

\author{
Farmers Social Capital in Increasing Agricultural Productivity in Sub Biraeng District of \\ Minasate'ne Pangkep \\ Besse Wulandari Aziz ${ }^{1}$,Tahir Kasnawi ${ }^{2}$, Sakaria $^{3}$ * \\ ${ }^{1}$ Mahasiswa Pascasrajana Sosiologi Fisip Universitas Hasanuddin, Makassar, Indonesia, email: wulandariazizb@gmail.com \\ ${ }^{2}$ Dosen Sosiologi Fisip Universitas Hasanuddin, Makassar, Indonesia, email: hirka_unhas@yahoo.com \\ ${ }^{3}$ Dosen Sosiologi Fisip Universitas Hasanuddin, Makassar, Indonesia, email: sakaria_anwar_ipb@yahoo.com
}

\section{A R T I CLE I N F O}

\section{How to Cite:}

Aziz, B. W., Kasnawi, T., \& Sakaria. (2019). Modal Sosial Petani dalam Peningkatan Produktifitas Pertanian di Kelurahan Biraeng Kecamatan Minasate'ne Kabupaten Pangkep. Hasanuddin Journal of Sociology (HJS), 1(1), 6674.

\section{Keywords:}

Trust, network, social norm, social capital, and productivity

\section{Kata Kunci :}

Kepercayaan, jaringan, norma sosial, modal sosial, dan produktivitas

\begin{abstract}
A B S T RA C T
Social capital plays an important role in improving agricultural productivity. Therefore, this study aims to determine and describe the potential of social capital and the contribution of farmers' social capital in improving agricultural productivity in Biraeng Urban District Minasate'ne Pangkep District. The research is a combination of quantitative and qualitative. Data collection techniques used are observations, questionnaires, interviews, literature review and dentation. Data analysis technique is in the form of primary data by using concurrent tiangulasi strategy. The results showed that the social capital potential of Biraeng urban village is high. This is in the description of three independent variables, namely trust (trust) variable shown by farmer group can simplify the affairs of 66,00\%, network variable shown by taking time interact with organization (farmer group) equal to $72,00 \%$, and variable of norm Social indicated by the existence of discipline in repaying loans amounted to $82.00 \%$. That is, trust, network, and social norms that are part of a farmer's social capital of one unit will increase agricultural productivity by one unit as well, and vice versa. So with a good trust between farmers and the elements that exist in the community, and not apart from the values and social norms that have been believed as a binding and regulating the rules of community life. The results of this study also shows that farmers' social capital positively affect agricultural productivity in Kelurahan Biraeng shown by T Statistics $=2.2823>t$ Table $=2.01290$.
\end{abstract}

\section{A B S T R A K}

Modal sosial sangat berperan penting dalam peningkatan produktifitas pertanian. Oleh sebab itu penelitian ini bertujuan untuk mengetahui dan

\footnotetext{
* Corresponding author. Tel.: 082300099919

E-mail address: wulandariazizb@gmail.com
} 
mendeskripsikan potensi modal sosial dan konstribusi modal sosial petani dalam meningkatkan produktivitas pertanian di Kelurahan Biraeng Kecamatan Minasate'ne Kabupaten Pangkep. Adapun penelitian ini merupakan gabungan antara kuantitatif dan kualitatif. Teknik pengumpulan data yang digunakan yaitu observasi, kuesioner, wawancara, kajian pustaka dan dukumentasi. Teknik analisis data berbentuk data primer dengan menggunakan strategi tiangulasi konkuren. Hasil penelitian menunjukkan bahwa potensi modal sosial petani Kelurahan Biraeng tinggi. Hal ini di uraian dari tiga variabel bebas yakni variabel kepercayaan (trust) ditunjukkan dengan kelompok tani dapat mempermudah urusan sebesar $66,00 \%$, variabel jaringan yang ditunjukkan dengan meluangkan waktu berinteraksi dengan organisasi (kelompok tani) sebesar 72,00 \%, dan variabel norma sosial yang ditunjukkan dengan adanya kedisplinan dalam membayar pinjaman sebesar 82,00 \% . Artinya, kepercayaan, jaringan, dan norma sosial yang merupakan bagian dari modal sosial petani sebesar satu satuan akan meningkatkan produktivitas pertanian sebesar satu satuan pula, begitu juga sebaliknya. Sehingga dengan kepercayaan yang baik antar petani dan unsur-unsur yang ada dalam masyarakat, serta tidak terlepas dari nilai-nilai dan norma sosial yang sudah diyakini sebagai aturan yang mengikat dan mengatur tatanan hidup bermasyarakat. Hasil penelitian ini juga menunjukkan bahwa modal sosial petani berpengaruh positif terhadap produktivitas pertanian di Kelurahan Biraeng yang ditunjukkan oleh T Statistik = 2,2823 > t - Tabel $=2,01290$.

(C) 2019 Hasanuddin Journal of Sociology. All rights reserved.

\section{PENDAHULUAN}

Indonesia merupakan negara agraris yang kaya akan sumber daya alam (SDA). Potensi tersebut penting untuk program pembangunan terutama di daerah pedesaan yang sebagian masyarakatnya bermukim di wilayah pedesaan dan bekerja pada sektor pertanian. Dengan kondisi yang demikian, wajarlah jika sumber daya fisik yang utama dan terpenting adalah tanah (lahan pertanian). Termasuk lahan yang ada di pedesaan umumnya digunakan untuk kehidupan sosial dan kegiatan ekonomi. Kegiatan sosial di antaranya berkeluarga, bersekolah, beribadah, berekreasi, berolah raga, dan sebagainya. Sedangkan penggunaan lahan untuk kegiatan ekonomi di antaranya kegiatan ekonomi bidang pertanian, perkebunan, perternakan, kehutanan, perindustrian, dan sebagainya. (Adon Nasrullah Jamaluddin, 2015:33)

Berbicara mengenai lahan pertanian, tentu tidak terlepas dari pembangunan pertanian. Pembangunan pertanian merupakan bagian dari pembangunan ekonomi. Pembangunan pertanian akan memperkuat dan menyumbang perekonomian secara keseluruhan. Oleh karena itu sektor pertanian perlu mendapat perhatian lebih karena besarnya persentase penduduk Indonesia yang hidup pada sektor ini.

Hal ini mendorong tingginya kontribusi sektor dalam pembentukan pendapatan belanja daerah (PBD), penyerapan tenaga kerja, penyediaan pangan, penurunan angka kemiskinan, dan penyediaan bahan baku dalam sektor-sektor industri. Pencapaian masyarakat pada sektor industri sebaiknya didukung oleh sektor pertanian sehingga pembangunan nasional akan menjadi tangguh. Memperkuat 
sektor pertanian dapat diartikan bahwa pembangunan nasional berupaya untuk meningkatkan kesejahteraan rakyat banyak dan ini watak ekonomi kerakyatan yang tercermin dalam keseluruhan kegiatan dan pelaksanaan ekonomi di Indonesia. (Nugroho,2006). Hubungan antara sektor pertanian dengan pembangunan nasional pada dasarnya merupakan hubungan yang saling berkaitan satu sama lain. Pembangunan nasional bertujuan untuk meningkatkan kualitas hidup masyarakat secara keseluruhan.

Penelitian ini bertujuan untuk mengetahui dan menganalisis potensi dan konstribusi modal sosial dalam meningkatkan produktifitas pertanian di Kelurahan Biraeng Kecamatan Minasate'ne Kabupaten Pangkep. Dengan demikian bahwa masyarakat Kelurahan Biraeng dalam hal ini mengalami kemajuan kesejahteraan serta perubahan lebih baik yang diakibatkan adanya peningkatan produktifitas pertanian.

\section{BAHAN DAN METODE}

\subsection{Lokasi dan Rancangan Penelitian}

Penelitian ini dilakukan di Kelurahan Biraeng Kecamatan Minasate'ne Kabupaten Pangkep Sulawesi Selatan. Jenis penelitian yang dilakukan adalah penelitian Gabungan yaitu kuantitatif dan kualitatif.

\subsection{Populasi dan Sampel}

Populasi dalam penelitian ini adalah seluruh kepala keluarga (KK) petani yang tinggal di Kelurahan Biraeng yang secara administratif terdaftar sebanyak 1.052 kepala keluarga tani dan sampelnya berjumlah 50 orang terdiri dari petani pemilik sejumlah 16 orang, petani penyewa sejumlah 16 orang, dan petani penggarap sejumlah 18 orang. Selain itu informan kunci yaitu: ketua Penyuluh Pertanian Kelurahan Biraeng dan ketua GAPOKTAN Kecamatan Minasate'ne Kabupaten Pangkep.

\subsection{Metode Pengumpulan Data}

Untuk mengumpulkan data dalam penelitian ini penulis menggunakan teknik pengumpulan data dengan cara Observasi, Kuesioner, Wawancara, serta, kajian kepustakaan dan dokumentasi.

\subsection{Analisis Data}

Teknik analisis data dalam penelitian gabungan yaitu kuantitatif dan kualitatif, kuantitatif dilakukan pada saat pengumpulan data berlangsung. Data kualitatif sebagai metode tambahan dengan observasi dan wawancara. (Creswell,2014).

\section{HASIL PENELITIAN}

Masyarakat pedesaan pada umumnya menggantungkan hidupnya pada sektor pertanian. Selain itu 
sektor pertanian merupakan salah satu penopang hidup masyarakat. Hal ini dapat dilihat dari mayoritas penduduk yang bermata pencaharian sebagai petani, didukung dengan kondisi tanah dan iklim tropis yang menjadikan tanah menjadi subur. Semua kelompok masyarakat (suku bangsa) pada hakekatnya mempunyai potensi-potensi sosial budaya yang kondusif dan dapat menunjang pembangunan pertanian. Terdapat penyeragaman modal yang bersifat materi.

Putnam (1995) dalam Pranadji (2006) menyatakan bahwa bangsa yang memiliki modal sosial tinggi cenderung lebih efisien dan efektif dalam menjalankan berbagai kebijakan untuk mensejahterakan dan memajukan kehidupan rakyatnya. Modal sosial dapat meningkatkan kesadaran individu tentang banyaknya peluang yang dapat dikembangkan sebagai kepentingan masyarakat terutama dalam kepentingan untuk meningkatkan hasil produksi pertanian. Selain itu Nugroho (2006) menyatakan bahwa modal sosial adalah penampilan organisasi sosial, seperti kepercayaan, norma-norma (atau habungan timbal balik), dan jaringan sosial yang terjalin dari ikatan-ikatan masyarakat. Penampilan organisasi sosial tersebut dapat memperbaiki efisiensi masyarakat dengan memfasilitasi adanya koordinasi dan kerjasama bagi keuntungan bersama.

Persoalannya selama ini modal sosial masih dipandang sebelah mata, belum menjadi perhatian para pengambil kebijakan dalam merumuskan kebijakan-kebijakan pembangunan termasuk di sektor pertanian. Padahal kita ketahui bahwa salah satu modal penting untuk berhasilnya suatu program pembangunan dengan modal sosial. Ada beberapa macam modal yang terdiri dari modal fisik, modal lingkungan, modal ekonomi, modal sosial dan modal-modal yang lainnya. Begitu penting modal sosial dalam pembangunan pertanian untuk meningkatkan Produktivitas hasil pertanian. Namun, tidak banyak orang mengakui bahwa bertambahnya modal manusia dan modal sosial dapat menaikkan tingkat produktivitas pertanian.

Menurut Loudry dalam Coleman (2009:415) Modal sosial merupakan sesuatu rangkaian proses hubungan sosial antara individu maupun antara kelompok yang dapat digunakan untuk menghasilkan sesuatu yang bernilai lain seperti saling percaya guna melakukan kerjasama demi meraih tujuan atau kepentingan bersama. tingginya nilai modal sosial yang dimiliki pada suatu daerah dapat membantu petani dalam hal produksi, distribusi dan inovasi. Misalnya apabila petani mengikuti kelompok tani, kemudian ketika kelompok tani tersebut mempunyai alat bajak untuk kepentingan kelompok, petani tersebut dapat dengan mudah memanfaatkan uang sewa alat bajak untuk keperluan lain, hal tersebut mengatakan bahwa modal sosial dapat mengurangi biaya tetap (fixed cost), Sawitri dan Soepriadi (dalam nurul 2016:4).

Tidak hanya itu modal sosial yang ditandai dengan banyaknya jumlah kelompok tani di daerah pedesaan, akan tetapi juga akan berguna untuk lebih cepat tersalurkannya aspirasi petani kepada pihak 
pemerintah. Modal sosial memberikan pengaruh yang besar terhadap para petani. Di Sulawesi Selatan sendiri Kabupaten Pangkep dan Sidrap terkenal dengan sebutan daerah "Lumbung Padi”. Salah satu Kelurahan di Kecamatan Minasate'ne yaitu Kelurahan Biraeng adalah daerah pertanian yang mempunyai lahan subur berpotensi menghasilkan panen tiga kali setahun. Di samping itu dengan modal sosial yang mereka miliki misalnya rasa empati sesama petani akan menimbulkan rasa kegotongroyongan antar warga di Kelurahan Biraeng. Dengan adanya saling kerjasama tersebut merupakan modal sosial yang memberikan konstribusi nyata terhadap Produktivitas pengolahan lahan yang berpengaruh langsung dalam peningkatan hasil pertanian.

Mengacu dari beberapa uraian tersebut serta penjelasan sebelumnya, maka dalam hal ini diperjelas bahwa modal sosial berpengaruh terhadap peningkatan produktivitas pertanian. Untuk mengetahui modal sosial masyarakat petani maka perlu diadakan pengujian data. Merujuk dari 24 indikator yang menjadi ukuran terhadap modal sosial, maka dapat disimpulkan bahwa masyarakat petani di Kelurahan Biraeng Kecamatan Minasate'ne mayoritas mengatakan setuju/ sering. Dari ke 24 indikator tersebut diambil 6 indikator yang paling menonjol untuk mengetahui besarnya tingkat kepercayaan (trust) yaitu: peminjaman peralatan tani, kepercayaan terhadap orang lain dalam menggarap sawah, memberikan tanggung jawab terhadap orang lain, meluangkan waktu mengikuti kegiatan kelompok tani, kegiatan kelompok tani dapat mempermudah urasan bertani, dan kelompok tani dapat meringankan masalah.

Berdasarkan dari tabel 1 maka hasil analisis dari indikator terdapat satu indikator yang paling menonjol yaitu kegiatan kelompok tani dapat mempermudah urusan bertani sebesar 66,00 \% . Hal ini didukung oleh wawancara dengan informan mengatakan bahwa, masyarakat petani Kelurahan Biraeng memiliki kepercayaan yang tinggi terhadap kelompok tani bahwa kelompok tani dapat mempermudah urusan bertani mereka. Ini menunjukkan bahwa masyarakat Kelurahan Biraeng memiliki tingkat kepercayaan yang tinggi. Seperti yang dikatakan informan bahwa keberadaan akan kelompok tani dapat membantu dan mempermudah urusan bertani seperti membantu dalam hal penyediaan pupuk dan pestisida serta informasi-informasi pertanian.

Selanjutnya masyarakat petani memiliki jaringan sosial diambil dari 5 indikator yang paling menonjol untuk mengetahui besarnya jaringan sosial yaitu : Tingkat kerjasama dalam mendapatkan bantuan, meluangkan waktu berinteraksi dengan kelompok tani, tingkat kehadiran dalam acara atau kegiatan kelompok tani, kerjasama dalam pembelian sarana produksi, peningkatan kerjasama dengan kelompok tani lain.

Berdasarkan dari tabel 2 maka hasil analisis dari indikator terdapat satu indikator yang paling menonjol yaitu terlihat bahwa masyarakat petani Kelurahan Biraeng Kecamatan Minasate'ne 
Kabupaten Pangkep meluangkan waktunya berinteraksi dengan kelompok tani lain sebesar 72,00\%. Hal ini didukung oleh wawancara dengan informan bahwa, masyarakat petani Kelurahan Biraeng sangat meluangkan waktunya berinteraksi dengan kelompok tani lain jika mengadakan rapat, Ini menunjukkan bahwa jaringan sosialnya tinggi. Seperti yang dikatakan informan bahwa ketika kelompok tani melakukan pertemuan masyarakat sangat bersemangat dan senang.

Selain itu masyarakat petani meiliki norma sosial yang berlaku dalam kehidupan masyarakat berdasarkan dari tabel 3 maka hasil analisis dari 6 indikator terdapat 3 indikator yang paling menonjol yaitu : Tingkat rasa syukur, Kedisiplinan dalam membayar pinjaman, kepedulian terhadap kelompok. Dari tabel 3 tersebut sehingga dapat diketahui bahwa dari ke tiga indikator tersebut maka terdapat satu yang paling menonjol yaitu masyarakat sangat disiplin dalam membayar pinjaman sebesar 82,00\%. Namun dari uraian tersebut menujukkan bahwa masyarakat sangat disiplin dalam membayar pinjaman/utang. Seperti yang dikatakan informan bahwa masyarakat sangat malu jika tidak tidak membayar pinjaman.

Hal yang sama yang dikataan oleh ketua gapoktan Kelurahan Biraeng Kecamatan Minasate'ne Kabupaten Pangkep bahwa para anggota yang meminjam pinjaman uang selalau tepat waktu dalam membayar utangnya pada saat setelah panen. Hal ini dilihat bahwa masyarakat petani sangat antusias serta bersemangat dalam melakukan kegitan pertaniannya. Karena masyarakat Minasatene umumnya adalah petani maka petani maka sumber penghasilannya adalah berasal dari hasil pertanian, Selain itu masyarakat petani sangat menjunjung tinggi norma yang berlaku dalam masyarakat seseuai dengan ketentuan yang berlaku.

\section{PEMBAHASAN}

Berdasarkan hasil penelitian yang dilakukan penulis, bahwa modal sosial masyarakat petani Kelurahan Biraeng Kecamatan Minasate'ne Kabupaten Pangkep tinggi dan mengalami perubahan. Berdasarkan dari hasil wawancara yang menjadi pendukung dalam penelitian bahwa masyarakat petani Kelurahan Biraeng setuju. Hal ini berarti masyarakat petani Kelurahan biareng Kecamatan Minasate'ne Kabupaten Pangkep sudah mengalami perubahan. Artinya Pencapaian masyarakat pada sektor industri sebaiknya didukung oleh sektor pertanian sehingga pembangunan nasional akan menjadi tangguh.

Secara umum modal sosial dapat didefinisikan sebagai hubungan sosial antara individu maupun antara kelompok yang dapat digunakan untuk menghasilkan sesuatu yang bernilai lain seperti saling percaya guna melakukan kerjasama demi meraih tujuan atau kepentingan bersama.

Putnam (2000) menyatakan bahwa modal sosial mengacu pada esensi dari organisasi sosial, seperti trust, norma dan jaringan sosial yang memungkinkan pelaksanaan kegiatan lebih terkordinasi, dan 
anggota masyarakat dapat berpartisipasi dan bekerjasama secara efektif dan efisien dalam mencapai tujuan bersama, dan mempengaruhi Produktivitas secara individual maupun berkelompok. Sementara itu Bourdieu mengemukakan bahwa modal sosial sebagai agregat sumber daya aktual ataupun potensial yang diikat untuk mewujudkan jaringan yang berjangka panjang sehingga menginstitusionalisasikan hubungan persahabatan yang saling menguntungkan satu sama lain. Selain itu modal sosial juga dapat mengembangkan potensi-potensi sosial yang dimiliki dalam masyarakat.

Bila dikaitkan dengan modal sosial, maka terdapat dua puluh empat ciri-cirinya yaitu: kepercayaan (trust), (meminjamkan peralatan tani, tanggung jawab, mendapatkan bantuan, percaya terhadap orang lain, percaya terhadap tetangga, tingkat keakraban, meluangkan waktu, memudahkan urusan, meringankan masalah), Jaringan (asosiasi,kejasama,meluangkan waktu berinteraksi, kehadiran dalam kegiatan, mendapatkan informasi, pemasaran usaha tani, kerjasama dengan kelompok tani lain, kerjasama mendapatkan sarana produksi, gotong royong memecahkan masalah), norma sosial (melakukan ritual sebelum menanam,wujud rasa syukur,membayar pinjaman, keberhasilan dalam bertani, kepedulian terhadap kelompok, kedisiplinan membayar iuran).

Masyarakat petani di Kelurahan Biraeng Kecamatan Minasate'ne Kabupaten Pangkep mengenai kepercayaan (trust) dan jaringan sosialnya sangat bagus dalam meluangkan waktunya ketika berinteraksi dengan orang lain. Hal ini terbukti pada saat kelompok tani mengadakan rapat maka masyarakat di Kelurahan Biareng Kecamatan Minasate'ne sangat antusias dan sangat bersemangat dalam mengikuti rapat selain itu karena masyarakat berfikir bahwa dengan mengikuti rapat tersebut maka para petani mendapatkan pengalaman-pengalaman baru serta ilmu baru dalam mengembangkan pertanian. Disisi lain juga masyarakat sangat memiliki potensi untuk menjadi petani yang profesional.

Kenyataannya ini juga terjadi di Kelurahan Biraeng Kecamatan Minasate'ne, dengan demikian bahwa masyarakat petani Kelurahan Biraeng sangat disiplin membayar iuran/pinjaman. Masyarakat Petani Kelurahan Biraeng mengalami perubahan yang signifikan, dimana masyarakat sebelum didirikannya kelompok tani belum terorganisir dalam membayar pinjaman disebabkan karena hanya mengharap terhadap tetangga atau keluarga mereka yang tidak memberikan batas waktu pembayaran. Selain itu dengan keberadaan kelompok tani yang mendirikan koperasi simpan pinjam masyarakat merasakan kemudahan mendapatkan pinjaman serta bantuan.

Masyarakat Petani Kelurahan Biraeng Kecamatan Minasate'ne dalam kehidupannnya juga terikat oleh norma-norma dimana seperti yang tergambarkan dalam masyarakat ada aturan-aturan kolektif yang biasanya tidak tertulis tapi dipahami oleh setiap anggota masyarakat dan menentukan pola tingkah laku yang diharapkan dalam konteks hubungan sosial. Menurut Fukuyama 2000 (Nursiah:2014), norma 
merupakan bagian dari modal sosial yang terbentuknya tidak diciptakan oleh birokrat atau pemerintah.

Norma terbentuk melalui tradisi, sejarah, tokoh kharismatik yang membangun sesuatu tata cara perilaku seseorang atau sesuatu kelompok masyarakat, didalamnya kemudian akan timbul modal sosial secara spontan dalam kerangka menentukan tata aturan yang dapat mengatur kepentingan pribadi dan kepentingan kelompok. Menurut Pranadji (2006) tingkah laku modal sosial penduduk secara langsung digambarkan melalui norma, nilai dan aturan yang berlaku dalam masyarakat tersebut.

Terkait dengan modal sosial, dapat kita lihat bahwa masyarakat sangat setuju dan menerima adanya peningkatan tingkat produktifitas pertanian. Karena masyarakat di Kelurahan Biraeng Kecamatan Minasate'ne sangat berharap selain masyarakat dapat meningkatkan pendapatan mereka juga memiliki pengalaman kerja dalam bidang pertanian. Karena sesuai dengan aturan serta usaha yang dilakukan oleh pemerintah khususnya pada kelompok tani yang ada di kabupaten pangkep. Bahwa setelah terjadi kesepakatan anatara kelompok tani dengan masyarakat maka akan menumbuhkan kerjasama dan rasa solidaritas yang tinggi. Selain itu juga para petani akan menjadi semakin memiliki jati diri yang kuat serta memiliki kepercayaan diri yang tinggi dengan kata lain bahwa modal sangatlah menjadi pendukung utama dalam mengembangkan pertanian untuk menuju masyarakat yang sejahtera.

\section{KESIMPULAN DAN SARAN}

Berdasarkan hasil penelitian yang dilakukan, maka dapat disimpulkan bahwa modal sosial petani dalam peningkatan produktivitas pertanian di Kelurahan Biraeng Kecamatan Minasate'ne Kabupaten Pangkep adalah signifikan, dengan T Statistik = 2,2823 $>\mathrm{t}-$ Tabel $=2,01290$ yang menunjukkan ada hubungan positif modal sosial terhadap produktivitas pertanian. Hal ini dapat dilihat pada elemen modal sosial yaitu kepercayaan (trust) sebesar 66,00, jaringan sosial sebesar 72,00 \%, sedangkan norma sosial sebesar 82,00 \%. Dari analisis tampak dalam keseharian masyarakat petani seperti: sifat kekeluargaan, sifat saling tolong menolong, saling membantu, kesetiakawanan, sikap koperatif,saling percaya kepada rukun tetangga, dan semuanya itu bisa terlihat dalam perilaku kolektif masyarakat seperti: sifat kerjasama, gotong-royong dan tentunya sikap partisipasi masyarakat petani. Selain itu berdasarkan hasil wawancara oleh masyarakat bahwa masyarakat di Kelurahan Biraeng Kecamatan Minasate'ne sudah mengalami perubahan dan menerima. Untuk pemerintah Kabupaten Pangkep agar terus melakukan perubahan serta meningkatkan pengembangan pertanian serta kepada masyarakat di kelurahan biraeng dalam rangka untuk memajukan masyarakat, khususnya masyarakat di kecamatan misate'ne. Dan untuk peneliti yang akan melakukan penelitian selanjutnya agar lebih fokus serta lebih mempertajam terhadap penelitian yang akan dilakukan. 


\section{REFERENCES}

Creswell. (2014). Research Design Pendekatan Kualitatif, Kuantitatif, Dan Mixed. Yogyakarta: Pustaka Pelajar.

Coleman, J.S. (2009) Social Capital in the Creatian of Human Capital in P. Dasgupta and I. Serageldin (Ed). Social Capital: A Multi faceted Perpective. Washington, DC: The World Bank.

Field, John. (2011). Modal Sosial. Cetakan Ke-2.PT. Kreasi Wacana.

Hanafist, (2013). Sejarah Perkembangan Pembangun Pertanian diIndonesia. (Online),(http://mhmmp.blogspot.co.id/2015/08/sejarah-perkembangan pembangunan.html, diakses 24 Agustus 2016)

Hadisapoetro, (1973). Pembangunan Pertanian. FP UGM Press. Yogyakarta.

Hawkins, (1999). Penyuluhan Pertanian. Cetakan ke-15. PT. Kanisius (Anggota IKAPI).

Jamaludin,Nasrullah, Adon. (2015). Sosiologi Pedesaan. Cetakan Pertama. Bandung: CV Pustaka Setia.

Marwanto, (2014). Statistik Daerah Kecamatan Minasate'ne 2014. BPS. Kabupaten Pangkajene dan Kepulauan.

Malik, Imam. (2015). Modal Sosial Petani Cengkeh dalam Mendukung Usaha Pertanian Tanaman Cengkeh (Studi Kasus di Desa Ketanda Kecamatan Sumpiuh Kabupaten Banyumas). (Online), (http://lib.unnes.ac.id/20609/1/3401411015-S.pdf, Diakses 25 September 2016)

Nugroho dkk., (2006). Dampak Kebijakan Pembangunan Pertanian Terhadap Pengentasan Kemiskinan Di Indonesia. Tesis yang diterbitkan. Bogor: Sekolah Pascasarjana Ilmu Ekonomi Pertanian - Institut Pertanian Bogor.

Nursinah. 2014. Modal Sosial "Siporio Siporennu" pada masyarakat Tani Kecamatan Patimpeng Kabupaten Bone Sulawesi Selatan.Tesis tidak diterbitkan. Makassar. Program Pascasarjana UNHAS.

Pranadji T. (2006). Penguatan Modal Sosial Untuk Pemberdayaan Masyarakat Pedesaan dalam Pengelolaan Agroekosistem Lahan Kering. Studi Kasus: Desa-desa (Hulu DAS) ex Proyek Bangunan Lahan Kering, Kabupaten Boyolali. Jurnal Agro Ekologi Vol. 24 No.2. (Online).diakses 24 Juli 2017. Dapat diunduh di: http://pse.litbang.deptan.go.id/ind/pdffiles/JAE\%2024-2d.pdf 